\title{
THE CONCEPT OF PREFERENCE AND ITS MANIFESTATION IN HUNGARIAN VERBAL CONFLICT SEQUENCES*
}

\author{
ÁGNES LERCH
}

\begin{abstract}
Preference is an operative notion of sequential organization and interpersonal understanding in conversation analysis. The complexity of the phenomenon that we are attempting to grasp through this notion has manifested itself in the seemingly controversial widening of the interpretation of the notion. In this paper I argue that preference can be interpreted through an inference rule as a consequence of the simultaneous but not equal manifestation of pragmatic principles; a deeper and uncontroversial interpretation of the notion is possible if, in addition to a structural inference rule and interpersonality principles, we take into consideration the role of rationality principles as well. In every communicative situation an interpersonal concern and a topical concern is operative; in consensus-oriented contexts preference structure is regulated by interpersonality principles that govern interpersonal relations and self-projection, while in conflict-oriented discourse the most important role is played by rationality principles. Approaching preference from the perspective of pragmatic principles may prove instrumental in integrating conversation analysis more closely with new directions and results of pragmatic research.
\end{abstract}

\section{Aims}

In this paper I attempt to clarify the nature of preference, considering that the use of this classical concept of conversation analysis (CA) which has an important part in interpreting utterances seems to have become confused and vague in the course of time. After reviewing the role of preference in CA in 2.1, in 2.2 through 2.5 I provide a critical survey of the interpretations of the term in the pragmatics literature. As a result of a reconsideration of the approaches at this issue, in 2.6 I suggest a complex interpretation of preference which unifies the different views from the perspective of pragmatic principles. In section 3, I investigate the manifestation of preference organization in verbal conflict sequences. In

\footnotetext{
* I would like to thank the two anonymous reviewers for their valuable comments and suggestions which helped improve the paper. All remaining shortcomings are, of course, my own responsibility.
} 
this part of this paper I argue that in order to grasp the nature of preference it is essential to investigate forms of agreements and disagreements in conflict talk. Section 4 summarizes the results.

\section{The concept of preference}

\subsection{The scope of preference}

Preference (preference organization) is a key analytical concept of CA, operative both in description and intersubjective understanding, because it is concerned with how actions are constituted and responded to, and how intersubjective understanding is achieved.

According to the CA literature, preference regulates, first of all, the choice among alternative but nonequivalent second parts of adjacency pairs, as well as the interpretation of the realized turns (Levinson 1983; Heritage 1984; Pomerantz 1984; Sacks 1995a;b). Although actions produced as first parts of adjacency pairs allow different reactions, they evoke expectations for specific preferred seconds. When the preferred alternative is not taken, it is experienced as being relevantly absent. Its noticeable absence is routinely used as a basis for inferences.

Preference is referred to as one of the most important discoveries of $\mathrm{CA}$, because it was central to the classic, early work on repair (Moerman 1977; Schegloff et al. 1977), responses to compliments (Pomerantz 1978), the organization of reference to others (Sacks-Schegloff 1979), responses to accusations (Atkinson-Drew 1979), and the placement of agreements (Sacks 1987).

As Pomerantz (1984) points out in her research into some features of second assessments in everyday friendly conversations, agreements are the preferred next actions after proffering initial assessments. Absences of forthcoming agreements are interpretable as instances of (as yet) unstated disagreements. Disagreements as well as other possible reactions (such as no talk, disagreements weakened by partial agreements, requests for clarification, challenging a presupposition or the competence of a coconversant) are less preferred than agreements, that is, they are dispreferred (to various degrees). Nowadays preference survives primarily in work on agreement and disagreement (Vuchinich 1990; Greatbatch 1992; Kotthoff 1993; Gruber 1996; Hayashi 1996; Gruber 1998; Boyle 2000).

In CA, preference is discussed largely in terms of responses to actions, but, according to the original concept established by Sacks (1995a;b; 
in particular Sacks 1995b, 367-9 and 444-52), the scope of preference is very much greater. It is concerned as much with initial actions as with responses, because preference is a feature of the constitution of all actions. $^{1}$

In addition, preference operates not only within adjacency pairs but also across entire alternative sequences ranking sets of sequence types, due to the possibility of the choice among various realizations of a sequence type and also among alternative sequence types (Schegloff et al. 1977; Schegloff 1979; Levinson 1983). ${ }^{2}$

Sacks regarded preference as a technical concept. Others (Atkinson -Heritage 1984; Bilmes 1988; 1991; Kotthoff 1993) emphasized also the original idea at later times, because the structural character of the notion has lost its importance in comparison with a psychological interpretation and a statistical approach to it as well. The differences in explicating the phenomenon of preference have given rise to some confusion that has resulted in establishing conflicting views on this matter, which I will discuss in sections $\mathbf{2 . 2 - 2 . 5}$ below.

\subsection{A structural approach to preference}

Sacks did not define preference exactly in his writings and lectures either (which enabled researchers to extend the meaning of the term later), he demonstrated what he has meant by preference by means of examples. In a lecture in April, 1971 (1995b, 367-9), Sacks said that there are preferred ways of formulating invitations: if one is inviting somebody for an evening during which dinner will be served, then that sort of information should be clearly included in the invitation or the invitee will have reason to assume that dinner will not be served. On the other hand, if the invitation is for an evening in which conversation will occur, this piece of information need not be included in the invitation. "Dinner" is a "first-preference invitation": if the formulation you select is not a first preference, then you are indicating that a first preference is not present. It is obvious that Sacks is not talking about preference in a psychological sense; he is not concerned with what any or all of the participants would prefer to do or say.

\footnotetext{
${ }^{1}$ For examples, see section $\mathbf{2 . 2}$ below and Boyle (2000, 599).

${ }^{2}$ For more details, see section $\mathbf{2 . 3}$.
} 
Bilmes $(1988,163)$ called attention to the invalidity of complementary inferences: if one displays one's work, a painting, an essay, or whatever, there is a preference for expressions of approbation from the person to whom the work is shown. That is, if no praise is forthcoming, it is relevantly absent, leading usually to the inference that the work has been judged unworthy of praise. The fact that the work is not explicitly dispraised, on the other hand, does not lead to the complementary inference that the work has been judged too good to be dispraised.

Bilmes (ibid.) highlighted two aspects of Sacks's notion of preference. One is the principle of ordering: (in the appropriate situation) do (or say) X, unless you have reason not to. This principle can be extended to include any number of ordered options: do $\mathrm{X}$, unless you have reason not to, in which case do Y, unless you have reason not to, in which case do $\mathrm{Z}$, and so forth. The other aspect manifests itself in the recognition that the existence of such rules of order is a basis for members' inferences. It is when the rules of order are used by members to make such inferences that we can speak of preference in the technical sense.

Bilmes (op.cit., 163-5) distinguished two types of preference, establishing a type $\mathrm{U}$ (unusual, unexpected) preference and a type $\mathrm{R}$ (relevant absence) preference.

Type $U$ preference is based on a rule of the following form: if $A$ is speaking to B on some subject, and A knows something unusual or unexpected about the subject which might be of significance to B, then A should mention it to $B$. Our inference is based on the assumption that the speaker follows the rule: if nothing unusual is mentioned, then we may conclude that the speaker knows of nothing unusual that might warrant mention. ${ }^{3}$ If the preferred alternative is not mentioned, it is not present.

The operative notion of type $\mathrm{R}$ preference is relevant absence. As mentioned in section $\mathbf{2 . 1}$ above, certain contexts make relevant some preferred action. When that action is not taken, it is relevantly absent. Its absence is noticeable and a basis for inference. ${ }^{4}$ (Type $\mathrm{U}$ preference is

${ }^{3}$ Bilmes (op.cit., 164) illustrates this point with the following example: if we are invited to a party, we do not go wearing a costume unless we are specifically advised that it is a costume party, and it is ordinarily the responsibility of the one issuing the invitation to volunteer such information on his or her own initiative. When we arrive in ordinary dress and discover that it is a costume party, this may be the basis for recriminations and apologies.

${ }^{4}$ Dinner was not mentioned in the invitation because no dinner will be served. Our work was not praised because it was not felt to be worthy of praise by our audience. 
also, in a way, a matter of relevant absence, that is, the absence of a preferred item is meaningful, but not necessarily noticeable. $)^{5}$

The rule generalized by Bilmes (op.cit., 165) is formulated as follows: preference operates with three (or more) alternatives: a preferred $(\mathrm{X})$, a nonpreferred $(\mathrm{Y}),{ }^{6}$ and no mention of $\mathrm{X}$ or $\mathrm{Y}(\mathrm{N}) .{ }^{7}$ The principle is that, if $\mathrm{X}$ is preferred, $\mathrm{N}$ implies $\mathrm{Y}$; conversely, if $\mathrm{N}$ implies $\mathrm{Y}$, then $\mathrm{X}$ is preferred. This rule has been extended primarily in the terms of type $\mathrm{R}$ preference over analysing adjacency pairs and alternative sequences as well.

\subsection{A (social) psychological dimension of preference}

According to Bilmes (1988), the loss of the purely formal character of preference is due, in part, to confusion between preference in its everyday usage and preference as a technical notion. The standard psychological sense of preference has a precedent in a lecture by Sacks (1987), first presented in $1973 .^{8}$

Following Sacks, Pomerantz (1984) added to the original criterion of preference (that is, relevant absence) the notion of markedness. Having observed that dispreferred responses are routinely associated with features that delay the production of the relevant response, for example, gaps, hesitations, qualifiers, weak agreements, ${ }^{9}$ side sequences, and so on, Pomerantz assumed that these features, called dispreference markers, correlate to dispreferred responses. Thereafter, it has been suggested in the CA literature that some features of turn/sequence organization operate with respect to the preference/dispreference status of actions: preferred

${ }^{5}$ Bilmes (op.cit., 164-5) demonstrates interesting ways in which type $\mathrm{U}$ and type $\mathrm{R}$ preferences may interact.

${ }^{6} \mathrm{Y}$ may include a set of nonpreferred actions.

${ }^{7}$ Bilmes (ibid.) illustrates the rule regarding both types: with type U preference, we can mention that something unexpected will occur, for example, that it will be a costume party $(\mathrm{X})$; we can mention that nothing unexpected will occur, for example, that it will be an ordinary party, with no special dress (Y); or we may omit any mention $(\mathrm{N})$. Likewise, with type $\mathrm{R}$ preference, we can mention something preferred, for example, that dinner will be served; we can mention something nonpreferred, for example, that dinner will not be served; or mention neither.

${ }^{8}$ The everyday usage is discussed in Atkinson - Drew (1979) and Owen (1983) as well.

${ }^{9}$ Weak agreements preface disagreements by agreeing with the prior speaker's position. 
responses are direct, often abbreviated, structurally simple, and typically immediate, dispreferred ones are typically indirect, structurally elaborated, and delayed. In explaining the phenomenon, Pomerantz (1984, 77) refers to sociability, support, and solidarity, that is, to psychological motivation.

Bilmes (1988, 173-4; 1991, 464-6) suggested that, although dispreference markers are associated with preference, they are part of a different, partly independent, phenomenon. Delays are, in fact, expressive of the speaker's reluctance to produce the response which should follow, consequently Bilmes refers to them as reluctance markers. He pointed out that reluctance markers do not necessarily accompany dispreferred utterances and may equally occur with preferred alternatives.

Accounts occurring very frequently in dispreferred actions are carefully formulated explanations for disagreements and refusals (Levinson 1983, 334). Considering that preferred actions do not include accounts, in the occurrence or absence of accounts we could at first sight expect a criterion of preference in a psychological sense. Bilmes (1991, 466) pointed out that it is inappropriate to correlate accounts with preference, because accounts regularly occur with disagreements and refusals, whether or not they are preferred. ${ }^{10}$

According to Taylor and Cameron $(1987,113-4)$, there is an obvious functional connection between some dispreferred second parts to adjacency pairs and the formal features of delay, mitigation, apology, etc., with which they are characteristically produced; namely, that their speakers would prefer (in the ordinary sense of the term) not to have been put in the position where they have to decline to produce the second pair part, which the first speakers obviously would have preferred (again, in its ordinary sense) to hear. Taylor and Cameron are of the opinion that it is inappropriate to attempt to maintain the early ethnomethodological claim that the differences between preferred and dispreferred actions are purely formal, with no basis in the truly psychological sense of preference: to say that one of two alternative acts is preferred to another is not to imply anything about the relevant speakers' own wishes, desires or motives. Others, Levinson (1983), Owen (1983), and Heritage (1984) among them, have acknowledged the psychological function of preference organization, too, by tying it to the notion of interactional "face work" established by Goffman (1955).

\footnotetext{
${ }^{10}$ For further details regarding preferred disagreements, see section $\mathbf{3}$.
} 
Toolan (1989) agrees with Taylor and Cameron (1987) to the extent that they emphasize the psychological and evaluative dimension of preference. At the same time, he criticizes them for attributing the psychological preferences to individual speakers. Toolan (op.cit., 264) argues that the psychological "tenor" carried by the preference organization is a collective normative protocol and may have little to do with the particular preferences of particular speakers in specific contexts. Interactants know that the collective social preference for example for invitations is to be met with acceptance, but that the collective preference pattern may not reflect the preferences of specific interactants. Preference organization is rooted in the norms and psychological preferences of the society and not the individual, as Toolan suggests (ibid.).

Concerning preference, Jacobs and Jackson (Jacobs-Jackson 1982; Jacobs 1987), emphasize the importance of such psychological notions as conventional desires or intentions accompanying speech acts ${ }^{11}$ (a request is conventionally recognized to express a desire that the other will comply to; the conventional desire expressed by an invitation is to accept it). Thus, a preferred response is one that fulfills the conventional desire or intention of the speech act, whether or not that conventional desire coincides with the speaker's actual desire. It is obvious that the conventions constituting speech acts have their roots in the norms of society.

The psychological interpretation of preference is striking also in essays which discuss the manifestation of preference in ranking alternative sequences. In their research on the organization of repair, Schegloff et al. (1977) revealed the following set of preferences (from the most preferred to the least preferred): preference 1 is for self-initiated self-repair in own turn (or in the transition space); preference 2 is for other-initiated selfrepair in the third turn; preference 3 is for other-initiated other-repair in the fourth turn; and, finally, preference 4 is for other-initiated otherrepair in the second turn, without inviting self-repair. Thus, the handling of repair coincides with the choice among alternative sequences.

Jefferson (1983) suggested that preference 4 above should be ranked higher (as preference 2) in the hierarchy if a speaker's error is replaced by the addressee within an utterance which includes important information besides repair. Jefferson accounts for the high ranking of this solution (called embedded correction) by pointing out that it avoids the risk of overtly challenging the speaker's competence.

${ }^{11}$ Investigating verbal interaction, Jacobs and Jackson unify the concepts and methods of CA and speech act theory. 
Investigating the initial turns of telephone calls, Schegloff (1979) set up a hierarchy of preferences in a similar way. He found that for telephone recognitions between known parties the preference is for both caller and recipient to provide the minimal cues (at best only greetings) they judge sufficient for the other to recognize the speaker. Overt self-identification is dispreferred because it challenges the familiarity of friendship.

Reviewing the CA literature in connection with requests, Levinson (1983, 360-1) suggests that after a pre-request there may be a preference for the avoidance of requests altogether. He sets up the following preference ranking operating over three kinds of sequences: most preferred is a pre-request - response to a non-overt request sequence; next preferred is a pre-request-offer-acceptance of an offer sequence; finally, the least preferred alternative is a pre-request - go ahead-request-compliance/ refusal sequence.

To invite an offer seems to be preferred to a request sequence because explicit requests risk refusal (Schegloff 1979, 49), which is a face threatening act (FTA). A motivation for applying pre-requests is avoiding an action (the request) that could obtain a dispreferred response (a rejection) and hence the checking of the most likely grounds for refusal (Levinson 1983, 356-64). In addition, requests threaten the addressee's negative face wants intrinsically by indicating (potentially) that the speaker does not intend to avoid impeding the addressee's freedom of action, as Brown and Levinson (1987, 65) point out.

To summarize the approaches mentioned before, Schegloff (1979), Jefferson (1983) and Levinson (1983) attribute the preference ranking operating over alternative sequences and sequence types to social psychological motivation: by choosing a preferred alternative, the speaker can avoid an action threatening his/her own face or the face of the addressee.

With reference to Heritage $(1984,268)$, Brown and Levinson (1987, 38-40) argue that face considerations seem to determine which kinds of responses are preferred vs. dispreferred. In their eyes, agreement is preferred because disagreement is an FTA; self-repair is preferred because correction by other may imply that self is incompetent; acceptances of offers or requests are preferred because the alternative refusals would imply lack of consideration; and so on. Similarly, they take many kinds of pre-sequences to be motivated by face considerations. 


\subsection{A statistical approach to preference}

Several conversation analysts - Schegloff, Jefferson and Sacks (1977), Sacks and Schegloff (1979), Levinson (1983), among others - tried to account for preference organization relying on frequency distribution. Arguing that people do what they prefer to do, and, so, if people overwhelmingly do a certain thing, this indicates a massive preference, they arrived at the conclusion that more frequently occurring alternatives must have a preferred status. Resisting the temptation to regard frequency of occurrence as a criterion of preference, most authors have used a more careful phrasing claiming that frequency distribution is evidence of preference organization. Schegloff et al. $(1977,362)$ found the fact that self-correction is "vastly more common than other-correction" to be "gross, prima facie evidence" of the preference for self-correction.

Bilmes $(1988,192)$ disapproved of the statistical approach to preference for two reasons. On the one hand, he criticized it because of the influence of the psychological sense of preference. On the other, he pointed out that the authors mentioned above have turned from the concept of preference to emphasizing ordering; ${ }^{12}$ that is, they were trying to account for what people do rather than for the inferences that people draw. Bilmes emphasized that preference governs interpretation, not production. However, if, contrary to him, we accept the social psychological motivation of preference, we can suppose with good reason that production corresponds to the expectations evoked by the preference/dispreference status of actions, because people follow the norms of society whenever possible.

\subsection{A complex interpretation of preference}

The latest interpretation of preference has been provided by Boyle (2000), after the publication of Sacks's lectures and building on them. Boyle gives an interpretation of preference that both accommodates the varied interpretations and provides a clear and simple account of the notion. He emphasizes that the clear and all-encompassing criterion of preference, in a Sacksian approach, is noticeable absence and accountability. At the same time, unlike Bilmes (1988), he does not consider connecting the

\footnotetext{
${ }^{12}$ Moreover, since a prescribed alternative may be unavailable, there is still a question of whether frequency of occurrence is strong evidence even of a principle of ordering (Bilmes 1988, 172).
} 
notion of preference with markedness, frequency distribution and face work as a false interpretation of preference but regards them as valid aspects of preference.

Boyle $(2000,586-7)$ accepts as valid the correlation of preference with markedness and frequency distribution to a limited degree (i.e., in the case of some sequences) and attributes the generalization of such correlations to the widely known work of Levinson (1983). Comparing views on the relationship of preference and face work, Boyle $(2000,588)$ points out, following Czyzewski (1989), that regarding preference as a consequence of social solidarity raises the question why actions are constituted as preferred or dispreferred. True to its ethnomethodological origins, however, CA is interested in finding out how speakers produce and understand preferred or dispreferred actions. ${ }^{13}$

According to Czyzewski (1989, 52-3), preferred actions contribute to the maintenance of social solidarity directly, while dispreferred actions do so indirectly; that is, the "social solidarity" argument is important, but it is not an adequate account of the phenomenon of preference. Nevertheless, Boyle states that in order to fully understand the concept of preference it is necessary to ally the issue of why individuals act as they do to the question of how they construct preferred and dispreferred turns.

Boyle considers social solidarity strengthening face work, markedness, and frequency distribution as such aspects of preference which do not constitute criteria of preference. Referring to Sacks's analyses along these lines, he argues that the criteria of preference, as demonstrated by Bilmes (1988) already, are noticeable absence and its (normative) accountability. The occurrence of a dispreferred action, that is, the nonoccurrence of a preferred, conditionally relevant action, calls for explanation. Here, Boyle $(2000,590)$ is the first to make a distinction between two types of dispreferred actions. One of them invokes no negative consequence or sanction. In this case, from an individual's failure to offer a greeting, for example, one might infer that the other person is deep in thought or does not recognize one, etc. These are acceptable accounts from which no sanctions should follow. In the other case, in a quite contrary fashion, the noticeable absence of an expected action gives rise to negative inferences and to sanctions: when another person fails to offer a greeting, one might account for the absence of the greeting by deciding that the action was deliberate and make negative inferences about the other person's character and behaviour.

${ }^{13}$ Bilmes (1988) called attention to this distinction as well. 
This distinction was not recognized before, and only the deliberate and sanctionable type of dispreferred actions was discussed in the literature. According to Boyle, this tendency might be a consequence of the implicit overgeneralization of the principle "trying to avoid the dispreferred action", at work in speakers' competence and recognized by Levinson $(1983,333)$. From this it follows that if one does not try to avoid a dispreferred action, this will be considered deliberate. However, it is clearly impossible, and not necessarily desirable, to avoid actions that are merely noticeable and accountable but not sanctionable.

The question that arises is that, if there is no explicit explanation, how does the co-conversant choose between the two possible accounts of the dispreferred action? Boyle answers this question only indirectly: the choice between the accounts is greatly influenced (even in the case of an explicit explanation) by the indexical knowledge of the situation and the co-conversant, the importance of which factors is stressed by Boyle (2000, 594-7) when, following Sacks, he points out how greatly these influence the speaker's decision in what is a preferred and what is a dispreferred answer to the question "How are you?" (from the point of view of the person asking it). ${ }^{14}$

Taking into account indexical knowledge does not question the significant role of normative accountability in interpersonal understanding but calls attention to the dangers of applying the norms automatically.

\subsection{Conclusion}

Considering the above, we can agree with Boyle that a complex interpretation of the concept of preference is necessary. But all approaches are equally important, none can be left out at the expense of the others, since they all grasp the essence of preference on different levels. Boyle fails to clarify this; he accepts the validity of the various interpretations, but, regarding the structural aspect most significant, he considers the others secondary.

Preference as a structural notion provides the descriptive inference rule of the mechanism of interpretation. The psychological approach stresses the reason of the preferred/dispreferred nature of actions. Pref-

\footnotetext{
${ }^{14}$ Throughout Sacks's discussion in 'Everyone has to lie' (1995a, 549-66) one is reminded of how close the everyday meaning of preference comes to the technical meaning of the concept.
} 
erence, from this aspect, is the expression of the social norm. This norm is described in the literature as interpersonality principles - principles which regulate interpersonal relations in communication and the selfprojection of the communicative partners (Németh T. 2003; 2004). Such principles are the politeness principle (Leech 1983; minimize the expression of impolite beliefs, and maximize the expression of polite beliefs, all other things being equal); the principle of face saving (Goffman 1959; save your own and your partner's face in communication); politeness strategies (Brown-Levinson 1987; strategies creating and maintaining negative and positive face, where negative face is people's desire that other people do not prevent them in their actions, while positive face is people's desire that their wishes, aims, attitudes etc. would be desirable for others as well). Finally, the statistical definition of preference is an empirical generalization.

In order to fully understand the concept of preference it is necessary but, as we will see in section $\mathbf{3}$, not sufficient to take into account the inference rule and the interpersonality principles.

\section{Preference in verbal conflict}

\subsection{The notion of verbal conflict}

Verbal conflict is a specific speech activity (Gumperz 1982,166) or activity type (Levinson 1992) the recognition and differentiation of which is part of the pragmatic competence of all the participants and the analyst. In verbal conflict the participants take turns attacking each other's utterances, actions or selves. The misunderstanding can conclude with one party's victory (and the other party's defeat), the voluntary acceptance of the opponent's position, a compromise, a stand-off, a withdrawal, or the intervention of a dominant third party. Verbal conflicts often remain unconcluded: in such cases the participants give up the opposition and start another (speech) activity (Vuchinich 1990).

All speech activities where these characteristics can be identified (naturally, only one of the possible conclusion types can occur in each situation) belong to the category of verbal conflicts, which range from a single episode to a confrontation encompassing an entire conversation. 
The critical discussion is a more strictly ordered type of verbal confrontation (see Eemeren-Grootendorst 1992, Eemeren et al. 1996). ${ }^{15}$

Conflict episodes are entities which comprise more than two turns and display structural properties which constrain the functions and interpretations of verbal contributions occurring in their course (Gruber 1998, 476) (see section 3.2). One piece of discourse can contain more than one conflict episode.

The manifestation of preference organization in verbal conflicts is important and even necessary to investigate, on the one hand, because in this speech activity preference structure of the statement-agreement/ disagreement sequence changes (see section 3.2), and this makes it necessary to interpret the concept of preference in such a way that it would be adequate for this context as well. On the other hand, arriving at a carefully argued conclusion on the issue of the correlation of preference and markedness requires an investigation of the manifestations of markedness in verbal conflicts. I attempt to do so in section $\mathbf{3 . 4}$ below.

\subsection{The preferred status of disagreement}

One of the long standing theses of CA is the preference of agreement over disagreement. This thesis is the generalization of the statement made by Pomerantz (1984) in an analysis of an adjacency pair consisting of an assessment and a response. The fact that this finding became considered generally valid for conversation is most likely due to the social psychological interpretation of preference. At the same time, Pomerantz (op.cit., 77-94) demonstrates that disagreement is preferred in response to self-deprecation: if it is lacking, dispreferred agreement is inferred. Elsewhere, Pomerantz (1978) states that agreement (especially in its unmitigated form) is dispreferred as a response to praise. ${ }^{16}$

There are clearly situations where disagreement is preferred. Accusations also operate contrary to the preference for agreement. With ref-

${ }^{15}$ The main parts of the critical discussion are the following: confrontation, debate opening, argumentation, and concluding decision. All of these can be characterized through the basic or complex speech acts typically realized in them, and, in addition to this, the argumentation part can also be described through the relevant argument schemata (Eemeren-Grootendorst 1992).

${ }^{16}$ Expressing or not expressing agreement and disagreement seems to be culturally specific (Clarke-Argyle 1982). The behaviour forms suggested by Pomerantz are valid only in European cultures and cultures similar to them. 
erence to Atkinson-Drew (1979) and Heritage (1984), Garcia (1991, 821) called attention to the fact that after accusations preference for agreement would lead to an admission of guilt as the preferred response to an accusation; for accusations, however, denials are the preferred response because the absence or delay of a denial may be interpreted as an admission of/evidence of guilt. ${ }^{17}$ Furthermore, Garcia (op.cit., 828) pointed out that denials in ordinary conversation tend to be placed immediately after the accusation, without delay, accounts, or other mitigating techniques. Accusations therefore make disagreement relevant and thus provide an interactional environment for escalation into disputes and arguments.

Bilmes (1988) investigated the preference status of the second part of adjacency pairs in the first part of which A attributes some action, thought, or attitude to B in B's presence: here, following the inference rule, there is a preference for $\mathrm{B}$ to contradict $\mathrm{A}$.

The nucleus of the verbal conflict, which can become the starting point for a single episode or a longer critical discussion, is a three-step introductory sequence (Gruber 1998, 477; Muntigl-Turnbull 1998, 227; Gruber 2001, 1822):

1. A: statement

2. B: counterstatement (i.e., disagreement with A)

3. A: counterstatement to B (i.e., disagreement with B and possibly insisting on 1)

Gruber (1998) argues that the occurrence of the third move by A is crucial for establishing a conflict episode, because if A reacts with any other action than a counterstatement to B (e.g., giving up his/her position, apologizing, or just being silent) in step 3, no conflict develops from the disagreement sequence (i.e., steps 1 and 2). The counterstatement produced in step 2 opens up the possibility of moving on to argumentation,

${ }^{17}$ According to Dersley-Wootton (2000, 387-8), Garcia's claim is overly general. Analysing sequences immediately following complaints and accusations, they differentiate between two types of denials, "didn't do" denials and "not at fault" denials. Denials of the "didn't do" type are characterized by features of preferred actions both in their form and their interpretation: the typical manifestation of this type of denial is not delayed, it is short and direct, and its lack (or delay) implies the admission of guilt. Denials of the "not at fault" type, which are often delayed, typically have two components: the complainee implicitly acknowledges some element of truth in the original complaint, but he or she overwhelmingly rejects any culpability for the action in question. The delay of a "not at fault" denial does not create a basis for participants to infer that the complainee accepts blame or guilt for the complained-of action. 
but it is only at step 3 that it will become clear whether the conversation can continue in a new context of developing the conflict or not.

Disagreement is preferred in the speech activity type of verbal conflicts - both in longer, argumentative discourse and in shorter sequences of verbal conflict (Bilmes 1991; Kotthoff 1993; Gruber 1996; 1998). According to the rule of preference, if a statement is not followed by disagreement, the inference that is made is that the statement is agreed with (or at least accepted). If, however, open agreement is not expressed, no inference of disagreement is made.

One of the findings of the investigation of verbal conflicts is the realization that preference structure is sensitive to context: unspecific friendly conversations are performed with an orientation toward consensus and agreement is preferred. However, as soon as a counterstatement occurs following disagreement during a conversation, the context specifications change: they become conflict-oriented, which, in turn, triggers a change in the preference structure. The participants orient each other to the expectation of disagreement, and disagreement will be the preferred interpretation (Bilmes 1991, 465-6; Kotthoff 1993, 194-5; Gruber $1998,471-6)$. In the case of institutional debate, the context is conflictoriented from the start.

\subsection{The data}

The corpus of data consists of audio cassette recorded and transcribed conversations from one radio and two television series of debate programs. All conversations occurred in spontaneously occurring argumentative discourse in live broadcasts. The corpus contains a total of 644 turns or 17,582 words.

Discourse produced in the media has been widely investigated (Heritage 1985; Hutchby 1992; Liddicoat et al. 1994; Gruber 1996; Hutchby 1996; Gruber 1998; Bilmes 1999; Gruber 2001; Lerch 2002), sometimes with this specific goal in mind, at other times in order to avoid the difficulties of collecting conversation data containing naturally occurring conflicts.

I investigated 10 dialogues, containing a total of 401 turns or 9,724 words, from the Hungarian call-in radio program Beszéljük meg! 'Let's discuss it' (by György Bolgár). ${ }^{18}$ (Below, the dialogues are referred to

\footnotetext{
${ }^{18}$ The length of each conversation is given in the Appendix.
} 
with the abbreviation LDI for the name of the program and the number of the dialogue.) According to the script of this program, at the beginning of each program the host introduces 3 or 4 topical issues of public interest, and then he takes telephone calls from the listeners. Callers are invited to reflect on one or more of the given topics but can introduce new topics only with the approval of the host. The aim of the conversation, according to the script of the program, is for the caller to fully explicate his/her position. In order to aid this, the host usually takes a point of view opposite with the caller and argues for it - thus, in most cases, a verbal confrontation develops between them, although it very rarely becomes confrontational (see LDI 7). Several politeness strategies occur in the conversations (Lerch 2002). The participation of the two participants in the conversation is more or less balanced. All ten dialogues follow a similar structure: it contains a loose flow of arguments for and against possible positions on one main topic (or one main topic and a side topic, in the case of two conversations, LDI 6 and 10), framed with and interrupted by sequences and episodes not containing verbal conflict.

In Aktuális 'Topical' (referred to with the abbreviation TOP below), a television debate program, the presenter carries on a longer conversation in the studio with one public personality (or sometimes two) about the leading news story of the day and other topical issues. The aim in this program is also that the guests expound on their positions and defend them. I used a stretch of discourse of 122 turns, or 3,475 words, from this program in my investigation. The participants use equal amounts of time in this program as well, and the extent of the confrontation depends on the topic (and the identity of the guest). In the stretch of discourse used for the present investigation a confrontational dispute developed: its structure is more pointed than those of the radio programs, and touches on three topics, from which three episodes containing verbal conflict develop.

In the television program Pro és kontra 'Pros and cons' (referred to with $\mathrm{P} \& \mathrm{C}$ below), according to the script, a moderator leads a dispute between two parties representing two opposing positions on an issue. In the stretch of discourse used for this investigation (of 121 turns, or 4,383 words), however, the confrontation is so sharp that the moderator almost has no chance to interrupt the conversation, and, thus, the participants of the dispute carry on a dialogue most of the time. This conversation follows the normative rules of critical discussion. 
Besides allowing to investigate markedness in both milder and sharper confrontations, the corpus also has the advantage of containing mostly semi-institutional conversations (LDI 1-10). Semi-institutional discourse is close to everyday conversation and is characterized by several of its features (Ilie 2001). In the discourse from the two television programs I analyse the institutional character is more dominant, but it is still not a typical example of institutional debate, especially as far as the linguistic manifestation of the confrontation is concerned. Thus, the observations made on the basis of the corpus will not be alien to everyday linguistic behaviour. The interpretation of preference would have to apply to the type of discourse investigated in this paper in any case.

\subsection{Markedness}

The corpus contains the following means of delay, called dispreference markers in the literature.

In turns realizing agreement, at the starts of turns speakers used hesitation, turn introducing prefaces (e.g., hát 'well', nézze 'look', na most 'well, now'), qualifiers (e.g., szerintem 'in my opinion', én úgy gondolom 'what I think is that...'), or a combination of these.

In turns realizing disagreement, turns also start with hesitation, prefaces, qualifiers, and also pauses, initiations of side sequences instead of disagreement (in order to delay disagreement), turn introducing agreement components, pro forma agreements, apologies, or a combination of these.

Next, in section 3.4.1, I will bring examples to the use of each of these markers. All the examples will be illustrated in turns realizing disagreement, partly because all of the markers can occur in this utterance type (while not all do in turns realizing agreement), and partly because, due to the preferred status of disagreement in this context, their occurrence is unexpected in these utterances (if we uphold the thesis of the existence of a correlation between preference and markedness). Following the examples, I demonstrate in tables the distribution of unmarked and marked realizations of agreement vs. disagreement in the corpus (section 3.4.2).

\subsubsection{Markers in turns realizing disagreement}

Abbreviations used in the identification of examples are as follows: letters (and, in some cases, numbers) before colons identify the source of the discourse (see the Appendix), letters after the colon identify the speaker(s) 
(also see the Appendix), while the letter identifying the speaker is followed by numbers which refer to the number of the first turn of the example within the stretch of discourse. (For other transcription conventions, see the Appendix.)

(i) Hesitation. Various forms of hesitation (including self-editing) have been identified in the literature (Levinson 1983, 334) as markers of dispreference (I give such markers in boldface in the examples). Hesitation signals the reluctance of the speaker to take a stand or his/her wish to delay it, in the case of both agreement and disagreement.

(1) (TOP: GYT10)

(Topic: erecting a statue to János Kádár)

GYT: Én azt gondolom, nem olyan lehetetlen. Hát ütnünk kell persze a vasat, és még nagyon sokat kell ebben az ügyben politizálni, de megmondom, hogy (.) szóval (.) két szempontot lehet mérlegelni. Az egyik, hogy ki volt Kádár János. Szóval azért Orbán Viktor is meg az ország minden vezetője tudja, hogy a közvélemény-kutatások mit mutatnak. Azok pedig azt mutatják, hogy Kádár Jánost a magyar nép úgy élte meg és úgy emlékezik rá, mint a század legkiemelkedőbb egyéniségére.

JB: De hát így - ezt így nem tudom - ja hogy vannak olyan közvéleménykutatások, amelyek (.) ö (.) hogy ha azt kérik, ez nem is vélemény, hanem hogy azt kérik, hogy kire emlékeznek hát h... hogy ez nagyon

GYT: Persze!

JB: =ez nem kétséges, de-hát-elöször is...

GYT: What I think is that it's not impossible. We have to strike the iron, yes, and have to do a lot of politics on the issue, but I tell you that (.) well (.) two aspects can be weighed. One is who János Kádár was. Well, Viktor Orbán and all the leaders of the country know what public opinion polls show. They show that János Kádár was experienced and is known to the Hungarian people as one of the most outstanding personalities of the century.

JB: But this way-I don't know about that -oh, you mean that there are polls that (.) er (.) that if you ask, this is not an opinion, that if you ask people who they remember well that. . that this lasted a [long time, $=$

Of course!

GYT:

JB: $\quad=$ no doubt, but - well - first of all... 
(ii) Prefaces. Whether they introduce agreement or disagreement, a preface signals that the participant does not find the previous position completely convincing.

(2) (TOP: JB100)

(Topic: the relationship of the Workers' Party and the Hungarian Socialist Party, HSP)

JB: A (.) kongresszuson mondott beszédében Elnök Úr (.) beszélt is erről az MSZP és a Munkáspárt viszonyáról, hogy- ̈- hogy (2.0) azt mondta, hogy az MSZP ne akadályozza a Munkáspártot, és hogy ne tegyenek olyan nyilatkozatokat, miszerint a Munkáspárt (2.0) ööö-a mai arculatával nem alkalmas arra, hogy együttműködjön vele az MSZP. Tehát tudja, hogy miről van szó többek között? Hát például hogy a (.) a (.) az iraki Bath-párttal kötött együttmüködési megállapodás az még érvényben van? Hát ilyesmiről.

GYT: Nézze, nem erről van szó. Arról-arról-arról van szó, kilencvennyolcban is ez történt és azóta is ez van, az MSZP az SZDSZ-szel akar együtt menni.

JB: In (.) your speech at the congress, Mr. President, you spoke about this, the relationship of the HSP and the Workers' Party, that - er that (2.0) you said that the HSP shouldn't hinder the Workers' Party, and they shouldn't make announcements to the effect that the Workers' Party (2.0) errr - with its current image is not suitable for the HSP to cooperate with. You know what it's all about? For instance, is the (.) the (.) the cooperation agreement signed with the Iraqi Bath Party still in effect? These kinds of things.

GYT: Look, that's not it at all. What-what-what it's all about is that this is what happened in ninety-eight, and this is what has been happening since, that the HSP wants to go with the AFD. ${ }^{19}$

(iii) Qualifiers. Qualifiers limit the validity of the position (of agreement or disagreement) expressed in the turn to the speaker.

(3) (P\&C: IKo15)

(Topic: dividing the media.)

IKo: Nem, azt gondolom, hogy ez piacgazdaság ma Magyarországon, demokrácia van, piacgazdaság van, a tulajdon szentségét tiszteletben tartja az állam, itt egy csomó magánlap jött létre, magánemberek pénzt fektettek be egy bizonyos áruba, mert a - az újság is áru, ezt nem lehet már befolyásolni. Befolyásolni lehet a közmédiát, ott viszont elég erőteljes szerep várhat a mostani politikai szereplőkre, de szerintem egészen más szerep, mint amit a Kerényi Imréék ezen és más demonstrációkon el-

${ }^{19}$ AFD: Alliance of Free Democrats. 
mondtak, én azt gondolom, hogy egy tisztességes, kiegyensúlyozott közszolgálati televíziót kell teremteni.

IKe: Nem hiszek benne, hogy ezt most meg lehet valósítani, szóval megbuktunk ezzel, Ilona. Egy olyan idegen modellt akartunk honosítani, ami ebben az országban nem honosítható...

IKo: No, I think that this is a market economy now in Hungary, we have democracy and a market economy, the sanctity of private property is respected by the state, a whole lot of private papers were established, private people invested money in a certain commodity, because newspapers are a commodity as well, this cannot be influenced any more. You can influence public media, but there you can expect for the current political personalities to have a pretty forceful role, but this role is, I think, very different from what Imre Kerényi and others were talking about in this and other demonstrations, and what I think is that a decent balanced public television should be created.

IKe: I don't believe in the possibility of carrying this out now, I think we failed with this, Ilona. We wanted to import a foreign model which cannot be imported into this country...

(iv) A turn introducing agreement component (weak agreement). It can be face saving as well as carry an important propositional meaning.

(4) (LDI10: GYB23)

(Topic: introducing a toll on a highway)

GYB: Igen, de ebből mégiscsak az a logikai következtetés vonható le, hogy aki használ valamit, aki bizonyos juttatásokhoz, örömhöz, nem tudom micsodához jut azáltal, hogy kutyát tart, vagy azáltal, hogy autót tart és autópályát használ, akkor az fizesse meg annak a költségét, nem? Tehát ne a kutyatulajdonos fizesse meg az autótulajdonos=

C: $\quad=$ Ebben tökéletesen igaza van, Bolgár Úr, de végső soron azok az utak is romlanak, amik nem az autópályához tartoznak, és ezt majd kinek kell karbantartani, ha áttevődik a forgalom?

GYB: Yes, but from this you can logically conclude that whoever uses something, whoever receives some kind of benefits, joy, whatever, from keeping a dog or from having a car and using a highway should pay for the expenses, shouldn't they? So, it shouldn't be the dog owner who pays for the car owner's=

$\mathrm{C}: \quad=$ You are perfectly right in this, Mr Bolgár, but those roads that are not part of the highway system are damaged, too, and who will be maintaining them if the traffic will move over to them?

(v) Pro forma agreement: the igen, de 'yes, but' strategy. It serves more of a connecting function in a sharp conflict, whereas in milder disputes 
the literal meaning of the phrase (agreement and face saving) plays a more important role in the interpretation.

(5) (LDI9: GYB9)

(Topic: whether the NATO ground forces will deploy in Kosovo)

GYB: Szóval hogy kiürüljön a terület, hogy aztán szabadon mozoghassanak a csapatok.

C: $\quad$ Pontosan, és pontosan ott, ahol a háborút lényegében a szerbek részéről is - az az egyik állásfoglalás az ő részükről, hogy olyan helyen legyen a háború, ha már elkerülhetetlen, ahol lényegében nem szerb lakosság van.

GYB: Igen, de mért lett volna érdeke ez a NATO-nak, hogy kiürüljön Koszovó, neki az lett volna feltételezésem szerint az érdeke, hogy bombázza a főbb célpontokat három napon keresztül, és Milosevics föltartja a kezét, azt mondja, hogy jó, egyezzünk meg így, ahogy akarjátok.

GYB: Well, so that the area is cleared of people and the troops could move around freely.

C: $\quad$ Exactly, and exactly where, from the point of view of the Serbs, the war is - that's their standpoint, that the war, if it's unavoidable, should be happening where the population is largely not Serbian.

GYB: GYB: Yes, but why would it have been in NATO's interest for Kosovo to be cleared of people, their interest would have been, I suppose, to bomb the major targets for three days, so Milosevic puts up his hands and says all right, let's come to an agreement the way you want to.

(vi) Apology (questioning one's competence). It can introduce agreement, too, even though I do not have an example of this in my corpus.

(6) (LDI6: GYB21)

(Topic: the war in Kosovo, and the peace process)

GYB: Talán a kormány abból indul ki, hogy mi csak egy tag vagyunk a tizenkilenc közül, ráadásul nagyon frissen fölvett, és bár valóban a mi érdekeink nagyon sokban különböznek a többi NATO-tagállamétól, de azért illúzió volna azt hinni, hogy egy magyar javaslatra reagálva majd a NATO vezető hatalmai, elsősorban az Egyesült Államok megváltoztatják a politikájukat, nem?

C: Megmondom őszintén, hogy én nagyon keveset értek a politikához, a katonáskodáshoz pedig végképp semmit, de úgy gondolom, hogy ebben a helyzetben minden eszközt meg kell ragadni arra, hogy Magyarországot valahogy kitereljük ebből a válságból. Nem afelé kell itt a dolgoknak haladni, hogy itt teljes jogú NATO-tagként, én nem tudom megérteni, hogy mért nem lehetett ezt megvétózni... 
GYB: Maybe the government thinks that we are only one of the nineteen members, and a very new member at that, and even though our interests are really very different from those of the other NATO member states, it would be an illusion to think that in reaction to a suggestion from Hungary the leading nations of NATO, especially the United States, will change their policy, wouldn't it?

C: $\quad$ I'll tell you frankly, I know very little about politics and even less about army matters, but I think that in this situation all means should be used to stir Hungary out of this crisis. Things shouldn't be going in the direction where as a NATO member of full rights, I can't understand why it wasn't possible to veto this...

(vii) Pause and side sequence. I discuss these two markers together because in my corpus significant pauses affecting interpretation occur only before initiations of side sequences. The following example, thus, illustrates multiple marking (see section 3.4.2).

(7) (LDI3: H22)

(Topic: intelligence scandal)

C: $\quad$ Na most - öö - hát - öö - ezek után tulajdonképpen mondjuk - öö elképzelhetőnek tartom, hogy - ööö-a hírszerzés jól dolgozott, nem? (3.0)

GYB: Hát-nem értem az összefüggést.

C: $\quad$ Öö-mert tulajdonképpen ezerkilencszázötvenhat(.)ban tulajdonképpen Horn Gyula-a-a-a-((coughs))

GYB: Karhatalmista volt.

C: Karhatalmi

GYB: Na de ezt nem kell titkosszolgálati módszerekkel vagy-nem (.) olyan módszerekkel, de egy titkosszolgálati szervezetnek földerítenie, mert hát (.) ö is elismerte.

C: $\quad$ Well, now - er - well - errr - after all this I can actually say - er - that I would consider it possible that - er - the intelligence did their job right, don't you think?

(3.0)

GYB: Well - I don't understand the connection.

C: $\quad$ Er-because actually in (.) nineteen fifty-six Gyula Horn actually - er ((coughs))

GYB: was a member of the special police squad.

C: $\quad$ Police squad

GYB: But this doesn't have to be uncovered with the means of the intelligence or-not with their special means, but an intelligence organization, because well (.) he admitted this, too. 
The pause and the side sequence initiated in the second turn signal the possibility of disagreement and, at the same time, delay its realization until the sixth turn. But the possibility of the realization of agreement is open until this sixth turn as well.

Having demonstrated that both preferred disagreement and dispreferred agreement can be introduced by so-called dispreference markers, in the following subsection I will discuss what the distribution is between unmarked and marked realizations of the two utterance types.

\subsubsection{Markedness and statistics}

In studying the realization of agreement and disagreement, I also took into consideration two other factors besides markedness: one is differentiating between the main topic vs. the side topic, and the other is the degree of the intensity of the conflict.

Both factors have been discussed in the literature, the former in connection with the study of agreement. Kotthoff $(1993,210)$ differentiates between partial agreement and agreement regarding the main topic of the conflict. Partial agreement concerns an unimportant aspect of the conflict or a side topic and closes the argument only as far as that is concerned, leaving the basic opposition unsolved. Agreement concerning an important aspect of the main topic brings the argument to an end, whereby the side topics lose their significance. This is rather face threatening because, if there is no compromise involved, it means that one of the parties was not able to defend his/her position. Such kind of agreement occurs in everyday conversations fairly rarely (Vuchinich 1990).

Kotthoff (ibid.) points out another distinction as well which can be important in investigating verbal conflicts: namely, the distinction between aggravated vs. mitigated disputes. The characteristics of aggravated disputes are as follows: a decrease of use or complete lack of delaying elements (the markers discussed above) and an increase of use of interruptions. Mitigated disputes are characterized by opposite tendencies. My corpus is balanced in this respect: about half of it contains sharp conflicts (LDI7, TOP and P\&C; a total of 296 turns, or 8,818 words), while the other half (the rest of the LDI recordings; a total of 348 turns, or 8,764 words) contains mild conflicts.

The following table demonstrates the distribution of various realizations of agreement in the corpus as far as the above-mentioned aspects are concerned. (S: sharp conflict (aggravated dispute); M: mild conflict (mitigated dispute).) 
Table 1

Distribution of the realizations of agreement

\begin{tabular}{|l|c|c|c|c|}
\hline \multirow{2}{*}{ AGREEMENT } & \multicolumn{2}{|c|}{ MAIN TOPIC } & \multicolumn{2}{c|}{ SIDE TOPIC } \\
\cline { 2 - 5 } & $\mathrm{S}$ & $\mathrm{M}$ & $\mathrm{S}$ & $\mathrm{M}$ \\
\hline \hline With no marker & $1(3 \%)$ & $9(26 \%)$ & $9(26 \%)$ & $5(14 \%)$ \\
\hline With hesitation & & $1(3 \%)$ & & \\
\hline With preface & & & & $2(6 \%)$ \\
\hline With qualifier & & & $1(3 \%)$ & \\
\hline With multiple marking & & $4(12 \%)$ & $2(6 \%)$ & \\
\hline
\end{tabular}

The corpus contains altogether 34 turns that realize agreement. In conflict-oriented discourse, as we have seen in section $\mathbf{3 . 2}$ above, agreement is a dispreferred response. Thus, if the markers were really markers of dispreference, marked cases should be in the majority. The data of the corpus, however, show an opposite tendency: agreement is realized without markers in 24 cases and with one or more markers in 10 cases. A tendency of unmarkedness predominates in aggravated disputes (10 unmarked and 3 marked), in mitigated disputes (14 unmarked and 7 marked), in agreement regarding the main topic (10 unmarked and 5 marked), as well as in agreement regarding the side topic (14 unmarked and 5 marked).

A tendency to avoid agreement regarding the main topic of the conflict is supported by the data for aggravated dispute but not for mitigated dispute.

The following table (Table 2) shows the distribution of the realizations of disagreement.

The corpus contains altogether 203 turns that realize disagreement. Of these, 71 are realized without markers, 132 with them. This also contradicts expectations in connection with preference status, since disagreement is preferred, and, thus, most of the cases should be unmarked. A tendency towards markedness is manifested in aggravated dispute (41 unmarked and 58 marked), mitigated dispute (30 unmarked and 74 marked), disagreement regarding the main topic (62 unmarked and 114 marked), and disagreement regarding the side topic (9 unmarked and 18 marked). This is the exact opposite of what we have seen in connection with agreement above.

Due to the limited size of the corpus it uses, this investigation aims to form (and support) hypotheses rather than test them. The results, as far as markedness is concerned, are that in conflict-oriented contexts marking works similarly to consensus-oriented contexts, i.e., agreement 
Table 2

Distribution of the realizations of disagreement

\begin{tabular}{|l|c|c|c|c|}
\hline \multirow{2}{*}{ DISAGREEMENT } & \multicolumn{2}{|c|}{ MAIN TOPIC } & \multicolumn{2}{c|}{ SIDE TOPIC } \\
\cline { 2 - 5 } & $\mathrm{S}$ & $\mathrm{M}$ & $\mathrm{S}$ & $\mathrm{M}$ \\
\hline \hline With no marker & $41(20.2 \%)$ & $21(10.3 \%)$ & & $9(4.5 \%)$ \\
\hline With hesitation & $2(1 \%)$ & & & \\
\hline With preface & $10(5 \%)$ & $5(2.5 \%)$ & $2(1 \%)$ & $2(1 \%)$ \\
\hline With qualifier & $4(2 \%)$ & $3(1.5 \%)$ & & $1(0.5 \%)$ \\
\hline $\begin{array}{l}\text { With turn introducing } \\
\text { agreement component }\end{array}$ & $10(5 \%)$ & $20(10 \%)$ & $1(0.5 \%)$ & $1(0.5 \%)$ \\
\hline With pro forma agreement & $4(2 \%)$ & $12(6 \%)$ & $2(1 \%)$ & $1(0.5 \%)$ \\
\hline With apology & $9(4.5 \%)$ & $8(4 \%)$ & $1(0.5 \%)$ & $3(1.5 \%)$ \\
\hline $\begin{array}{l}\text { With insertion of } \\
\text { side sequence }\end{array}$ & $11(5.4 \%)$ & $16(8 \%)$ & $1(0.5 \%)$ & $1(0.5 \%)$ \\
\hline With multiple marking & & & $1(0.5 \%)$ & $1(0.5 \%)$ \\
\hline
\end{tabular}

tends to be unmarked, while disagreement is more likely marked. The rule of interpretation of preference, as we have seen, does not allow the supposition that agreement is preferred in verbal conflicts. Markers, then, as Bilmes (1988) also believed, do not mark dispreference in the structural sense: their occurrence is motivated by some other factor.

\subsection{An attempt to explain}

In this section I will attempt to answer the question of what motivation lies behind the preference of disagreement in verbal conflicts.

According to Kotthoff $(1993,209)$, in a fully developed dispute, concession (i.e., the acceptance, without reservations, of the opposing position of the other disputant) is a dispreferred act because it threatens the positive face of the speaker, while disagreement protects it, in the sense of Goffmann (1967) and Brown-Levinson (1987). As we have seen above, proponents of the psychological approach to preference also refer to the interpersonality principles of mutual protection of face, the politeness principle, and politeness strategies.

At this point, let us make a detour and take another look at the preference structure of adjacency pairs investigated by Bilmes (1988), where in the first pair part the speaker attributes some kind of thought or action to the co-conversant. In this kind of adjacency pair disagreement 
is the preferred response while agreement is dispreferred, since a lack of utterance equals agreement and not disagreement. Let us notice, however, (and this is something Bilmes does not point out) that the thought or action attributed to the co-conversant can be of any kind - not only positive or negative but also neutral - but this does not affect the preferred status of disagreement at all. In the case of a neutral statement it is not plausible to account for the preferred status of disagreement and the dispreferred status of agreement with face work.

Bilmes $(1991,465)$ points out that many, perhaps most of the statements we make that could potentially be agreed or disagreed with are made without an expectation of expressions of either agreement or disagreement; in such cases it is agreement that is presumed (although not expected), and it is disagreement that is preferred (according to the inference rule of preference).

In my opinion, in the case of neutral statements, which do not directly affect the face of the participants, it is primarily the truth of the propositional content of the utterance which is at stake. This, I believe, is largely true of disputes as well: we cannot accept as the only explanation the claim that in disputes disagreement is triggered solely by the speaker's desire to defend his/her point of view (and, through it, his/ her face). Equally important, or perhaps even more important, is the motivation to uncover the truth in the course of the dispute.

The main point I want to make with all of this is that in our investigations of norms and principles that explain preference, besides interpersonality principles, we should not forget about rationality principles.

Grice's Maxim of Quality (Grice 1975) - a classic rationality principle - is of crucial importance in explaining the preferred status of disagreement in adjacency pairs involving a (counter)statement in their first part. The Maxim of Relevance (Grice, ibid.), too, contributes to explaining the preference structure of adjacency pairs in verbal conflicts: the absence of an irrelevancy claim ${ }^{20}$ triggers the inference that the speaker agrees with his/her partner(s) in finding the previous claim to be relevant to the discussion at hand. Further rationality principles which can be connected with preference organization are Levinson's (2000) I-Principle and Q-Principle.

In his latest book about generalized conversational implicatures and the rationality principles underlying them, Levinson (2000) does not dis-

\footnotetext{
${ }^{20}$ For more details, see Muntigl-Turnbull (1998).
} 
cuss preference organization, nevertheless he makes remarkable observations on the level at which systematic pragmatic inferences must be explicated $^{21}$ as well as on the manifestation of the I-Principle in a phenomenon examined by conversation analysts.

Exploring I-inferences generated by the operation of the Principle of Informativeness (the I-Principle for short), Levinson (2000, 112-5) cites the pattern of self-identifications over the telephone observed by Schegloff (see section 2.3), where intimates expect their identity to be conveyed just by the sample of voice quality in their first Hello, only escalating step by step, when overt recognition is withheld, with further examples of voice quality, then nicknames or firstnames. The I-Principle (a rendition of Grice's Q2 maxim: do not make your contribution more informative than is required) is formulated as follows: "Say as little as necessary, that is, produce the minimal linguistic information sufficient to achieve your communicational ends (bearing Q in mind)" 22 (Levinson 2000, 114). Schegloff (1979) attributed the dispreferred status of overt self-identifications to social psychological motivation. In my opinion, face saving and a tendency towards economy, i.e., interpersonality and rationality principles, seem always to be at work simultaneously in the course of communication.

Levinson's First (Q-) Heuristic (Levinson 2000, 35) - "what isn't said, isn't" - is related to Grice's first Maxim of Quantity, Q1: make your contribution as informative as is required. Levinson's Q-Principle (developed from the First Heuristic) is formulated as follows: "Do not provide a statement that is informationally weaker than your knowledge of the world allows, unless providing an informationally stronger statement would contravene the I-Principle. Specifically, select the informationally strongest paradigmatic alternate that is consistent with the facts"

${ }^{21}$ In contrast to the standard view, according to which there are only two levels of meaning, Levinson (2000, 22-3) assumes three levels of meaning: (i) sentencemeaning, (ii) utterance-token-meaning, and (iii) a level of meaning between the first two, i.e., utterance-type-meaning. Sentence-meaning must be explicated by a theory of grammar, utterance-token-meaning (or speaker-meaning) is a matter of actual nonce inferences made in actual contexts by actual recipients. At the level of utterance-type-meaning systematic pragmatic inferences independent of particular contexts can be captured. These systematic pragmatic inferences, such as preference organization, among others, are based not on direct computations about speaker-intentions but on general expectations about how language is normally used.

${ }^{22}$ See the definition of $\mathrm{Q}$ in the next paragraph. 
(Levinson 2000, 76). Considering this, Sacks's classic "dinner" example (see section 2.2) and similar phenomena can obviously be analysed as generalized conversational implicatures induced by the Q-Principle.

According to Németh T. $(2003,248 ; 2004,410)$, the rationality principles guide information transmission and interpretation with reference to the object. This kind of information, expressed explicitly or implicitly, is basically propositional in nature. Interpersonality principles regulate information transmission and processing on selves including the communicative partners' desires, wishes, aims, etc. This kind of information does not necessarily have a propositional form, sometimes it can hardly be propositionalized. Considering this, Gruber's (1998) investigations confirm the assumption that rationality principles are crucial in explaining preference structure in verbal conflict sequences, inasmuch as he proves that the more vehement the dispute is, the more important the propositional content and the thematic cohesion of the turns are.

We have now run a full circle. My answer to the question what we should understand by preference is, then, this: I understand preference as a phenomenon which is motivated by rationality and interpersonality principles and manifested in the norms of linguistic behaviour, and whose mechanism is described by an inference rule.

From the perspective of the above argumentation it seems plausible to interpret the linguistic means called dispreference markers in the classic works of CA and reluctance markers since Bilmes (1988) on the basis of interpersonality and rationality principles together. Without any doubt, reluctance markers play a role in protecting the face of the partner. In the case of a critical discussion - especially a sharp one - it would be strange, however, to state that any one of the markers - for instance, the agreement component as a preface of an utterance realizing disagreementserves exclusively or even just primarily the purpose of expressing politeness and protecting the face of the partner. In such cases it is equally (if not more) important to clash positions and arguments, and the propositional content of the agreement component is also important in addition to its interpersonal effect. In the use of all the discussed markers the weighing of the propositional content of the utterance is most likely to play a role. The same is true for explanations and justifications provided in the same turn as a disagreement - these are also included among dispreference markers (although not among reluctance markers) - since an explanation or a justification used as an argument is an important element of the content of the dispute. We can suppose, then, that on the 
basis of the principles of communicative language use discussed a comprehensive description of general validity can be provided about the use of these markers. An attempt at providing such a description, however, is beyond the scope of the present paper.

\subsection{Statistical distribution}

In the course of dispute, due to the nature of the phenomenon, preferred disagreement is most likely to be more frequent than dispreferred agreement is, since as soon as the opposite is the case, we can no longer speak of dispute. Frequency distribution agrees with preferential structure in the case of verbal conflicts. The data of the investigated corpus support this: it contains 203 turns realizing disagreement and only 34 turns realizing agreement. This, however, does not mean that the frequency distribution correlates with preferential status in the case of every sequence type.

\section{Summary}

In the present paper I have attempted to clarify the nature of preference considering that the use of this classical concept of conversation analysis seems to have become confused in the course of time.

After discussing the scope of preference in CA, I have first demonstrated Sacks's original concept of preference. Then, rewieving changes in the interpretation of the concept, I have studied the attempts aimed at defining it, categorizing them as structural, social psychological, statistical and complex approaches. I have argued for the complex approach, suggesting a new interpretation of preference which unifies the different views from the perspective of pragmatic principles. I have attributed the various aspects of preference to the joint manifestation of the interpersonality principles regulating the interpersonal relationships of the speakers (such as the principle of saving face, the politeness principle and politeness strategies) and rationality principles directed at the object of the utterance (such as Grice's Maxim of Quality and Maxim of Relevance, Levinson's Q-Principle and I-Principle). I have emphasized that the maxims of quality and relevance play a crucial role in understanding the preference structure of adjacency pairs involving a counterstatement in their first part. 
I have investigated preference structure and markedness in a corpus of transcribed conversations from debate programs on Hungarian radio and television in order to interpret the concept of preference with regard to its context sensitivity and to arrive at a carefully argued conclusion on the issue of the correlation of preference and markedness. After discussing examples, I have demonstrated in tables the distribution of unmarked and marked realizations of agreement vs. disagreement in the corpus. The results have confirmed the assumption known in the literature but not checked in a corpus that preference does not correlate with markedness, consequently the markers investigated are not dispreference markers but reluctance markers.

Finally, I have proposed a new approach to reluctance markers to interpret them on the basis of interpersonality and rationality principles together.

\section{Appendix}

\section{The data of the corpus}

Discourse transcribed from audiotapes:

1. radio programs

LDI1: Let's discuss it (Beszéljük meg!) Program by György Bolgár. 26 March 1998.

31 turns, 1061 words

LDI2: Let's discuss it (Beszéljük meg!) Program by György Bolgár. 26 March 1998.

23 turns, 1032 words

LDI3: Let's discuss it (Beszéljük meg!) Program by György Bolgár. 26 March 1998.

79 turns, 973 words

LDI4: Let's discuss it (Beszéljük meg!) Program by György Bolgár. 26 March 1998.

48 turns, 779 words

LDI5: Let's discuss it (Beszéljük meg!) Program by György Bolgár. 7 April 1999.

21 turns, 719 words 
LDI6: Let's discuss it (Beszéljük meg!) Program by György Bolgár. 7 April 1999.

36 turns, 1058 words

LDI7: Let's discuss it (Beszéljük meg!) Program by György Bolgár. 22 April 1999.

53 turns, 960 words

LDI8: Let's discuss it (Beszéljük meg!) Program by György Bolgár. 22 April 1999.

43 turns, 1297 words

LDI9: Let's discuss it (Beszéljük meg!) Program by György Bolgár. 22 April 1999.

27 turns, 830 words

LDI10: Let's discuss it (Beszéljük meg!) Program by György Bolgár. 22 April 1999.

40 turns, 1015 words

In all conversations: GYB: György Bolgár; C: caller

2. television programs

TOP: Topical (Aktuális). 6 July, 2001. János Betlen talking to Gyula Thürmer, President of the Workers' Party.

122 turns, 3475 words

JB: János Betlen; GYT: Gyula Thürmer

P\&C: Pros and cons (Pro és kontra). Debate between Imre Kerényi and Ilona Kocsi. 5 September, 2002.

121 turns, 4383 words

IKe: Imre Kerényi; IKo: Ilona Kocsi

\section{Transcription conventions}

((coughs)) double parantheses: certain meaningful (mostly non-verbal) details of the scene

.) micropause; potentially significant but very short pause, comparable to the duration of an average syllable

(2.0) measured pause (in seconds)

- $\quad$ dash: a short unmeasured pause within an utterance

lehet underline: emphasis 
nem left-hand bracket: the point at which an ongoing utterance is joined by another

persze

equal signs are used to link different parts of a single speaker's utterance when those parts constitute a continuous flow of speech that has been carried over to another line, by transcript design, to accommodate an intervening interruption when there is no interval between adjacent utterances; an equal sign also signals a lack of pause or overlap between two utterances

\section{References}

Atkinson, J. Maxwell-Paul Drew 1979. Order in court: The organization of verbal interaction in judicial settings. Humanities Press, Atlantic Highlands NJ.

Atkinson, J. Maxwell- John Heritage (eds) 1984. Structures of social action: Studies in conversation analysis. Cambridge University Press, Cambridge.

Bilmes, Jack 1988. The concept of preference in conversation analysis. In: Language in Society $17: 161-81$.

Bilmes, Jack 1991. Toward a theory of argument in conversation: The preference for disagreement. In: Frans H. van Eemeren-Rob Grootendorst-Anthony J. BlairCharles A. Willard (eds): Proceedings of the Second International Conference on Argumentation, 462-9. SICSAT, Amsterdam.

Bilmes, Jack 1999. Questions, answers and the organization of talk in the 1992 vice presidential debate: Fundamental considerations. In: Research on Language and Social Interaction $32: 213-43$.

Boyle, Ronald 2000. Whatever happened to preference organisation? In: Journal of Pragmatics $32: 583-604$.

Brown, Penelope-Stephen C. Levinson 1987. Politeness: Some universals in language usage. Cambridge University Press, Cambridge.

Clarke, David D. - Michael Argyle 1982. Conversation sequences. In: Colin FraserKlaus R. Scherer (eds): Advances in the social psychology of language, 159-240. Cambridge University Press, Cambridge.

Czyzewski, Marek 1989. Garfinkel, 'cognitive revolution', and conversation analysis. In: International Journal of the Sociology of Language 78:43-55.

Dersley, Ian - Anthony Wootton 2000. Complaint sequences within antagonistic argument. In: Research on Language and Social Interaction 33:375-406.

Drew, Paul - John Heritage (eds) 1992. Talk at work: Interaction in institutional settings. Cambridge University Press, Cambridge.

Eemeren, Frans H. van-Rob Grootendorst 1992. Argumentation, communication and fallacies. Lawrence Erlbaum, Hillsdale NJ. 
Eemeren, Frans H. van-Rob Grootendorst-Francisca Snoeck Henkemans 1996. Fundamentals of argumentation theory. Lawrence Erlbaum, Mahwah NJ.

Garcia, Angela 1991. Dispute resolution without disputing: How the interactional organization of mediation hearings minimizes argument. In: American Sociological Review $56: 818-35$.

Goffman, Erving 1955. On face-work: An analysis of ritual elements in social interaction. In: Psychiatry $18: 213-31$.

Goffman, Erving 1959. The presentation of self in everyday life. Doubleday Anchor, Garden City NY.

Goffmann, Erving 1967. Interaction ritual. Doubleday Anchor, Garden City NY.

Greatbatch, David 1992. On the management of disagreement between news interviewees. In: Drew - Heritage (1992, 268-301).

Grice, H. Paul 1975. Logic and conversation. In: Peter Cole- Jerry L. Morgan (eds): Syntax and semantics, vol. 3: Speech acts, 41-58. Academic Press, New York.

Gruber, Helmut 1996. Streitgespräche: Zur Pragmatik einer Diskursform. Westdeutscher Verlag, Opladen.

Gruber, Helmut 1998. Disagreeing: Sequential placement and internal structure of disagreements in conflict episodes. In: Text 18:467-503.

Gruber, Helmut 2001. Questions and strategic orientation in verbal conflict sequences. In: Journal of Pragmatics $33: 1815-57$.

Gumperz, John 1982. Discourse strategies. Cambridge University Press, Cambridge.

Hayashi, Takuo 1996. Politeness in conflict management: A conversation analysis of dispreferred message from a cognitive perspective. In: Journal of Pragmatics 25 : $227-55$.

Heritage, John 1984. Garfinkel and ethnomethodology. Polity Press, Cambridge.

Heritage, John 1985. Analyzing news interviews: Aspects of the production of talk for an overhearing audience. In: Teun A. van Dijk (ed.): Handbook of discourse analysis, vol. 3: Discourse and dialogue, 95-117. Academic Press, New York.

Hutchby, Ian 1992. Confrontation talk: Aspects of 'interruption' in argument sequences on talk radio. In: Text $12: 343-71$.

Hutchby, Ian 1996. Confrontation talk: Arguments, asymmetries and power on talk radio. Lawrence Erlbaum, Mahwah NJ.

Ilie, Cornelia 2001. Semi-institutional discourse: The case of talk shows. In: Journal of Pragmatics $33: 209-54$.

Jacobs, Scott 1987. The management of disagreement in conversation. In: Frans H. van Eemeren - Rob Grootendorst - J. Anthony Blair-Charles A. Willard (eds): Argumentation: Across the lines of discipline. Proceedings of the conference on argumentation 1986, 229-59. Foris, Dordrecht.

Jacobs, Scott-Sally Jackson 1982. Conversational argument: A discourse analytic approach. In: J. Robert Cox-Charles A. Willard (eds): Advances in argumentation theory and research, 205-37. Southern Illinois University Press, Carbondale IL.

Jefferson, Gail 1983. On exposed and embedded correction in conversation. In: Studium Linguistik $14: 58-68$. 
Kotthoff, Helga 1993. Disagreement and concession in disputes: On the context sensitivity of preference structures. In: Language in Society $22: 193-216$.

Leech, Geoffrey N. 1983. Principles of pragmatics. Longman, Harlow.

Lerch, Ágnes 2002. Normatív argumentáció, argumentációs stratégia és az udvariasság elve [Normative argumentation, argumentative strategies and the politeness principle]. In: Márta Maleczki (ed.): A mai magyar nyelv leírásának újabb módszerei V [Recent methods in the description of contemporary Hungarian 5], 421-46. Szegedi Tudományegyetem, Szeged.

Levinson, Stephen C. 1983. Pragmatics. Cambridge University Press, Cambridge.

Levinson, Stephen C. 1992. Activity types and language. In: Drew-Heritage (1992, 66100).

Levinson, Stephen C. 2000. Presumptive meanings: The theory of generalized conversational implicature. MIT Press, Cambridge MA.

Liddicoat, Anthony - Susanne Döpke-Kristina Love-Anne Brown 1994. Presenting a point of view: Callers' contributions to talkback radio in Australia. In: Journal of Pragmatics $22: 139-56$.

Moerman, Michael 1977. The preference for self-correction in a Tai conversational corpus. In: Language $53: 872-82$.

Muntigl, Peter - William Turnbull 1998. Conversational structure and facework in arguing. In: Journal of Pragmatics 29:225-56.

Németh T., Enikő 2003. A kommunikatív nyelvhasználat elvei [The principles of communicative language use]. In: Általános Nyelvészeti Tanulmányok 20 :221-54.

Németh T., Enikő 2004. The principles of communicative language use. In: Acta Linguistica Hungarica $51: 379-418$.

Owen, Marion 1983. Apologies and remedial exchanges: A study of language use in social interaction. Mouton, Berlin.

Pomerantz, Anita 1978. Compliment responses: Notes on the co-operation of multiple constraints. In: Jim N. Schenkein (ed.): Studies in the organization of conversational interaction, 79-112. Academic Press, New York.

Pomerantz, Anita 1984. Agreeing and disagreeing with assessments: Some features of preferred/dispreferred turn shapes. In: Atkinson-Heritage (1984:57-101).

Psathas, George (ed.) 1979. Everyday language: Studies in ethnomethodology. Irvington, New York.

Sacks, Harvey 1987. On the preferences for agreement and contiguity in sequences in conversation. In: Graham Button - John R. E. Lee (eds): Talk and social organisation, 54-69. Multilingual Matters, Clevedon.

Sacks, Harvey 1995a. Lectures on conversation. Vol. I. Blackwell, Cambridge MA \& Oxford.

Sacks, Harvey 1995b. Lectures on conversation. Vol. II. Blackwell, Cambridge MA \& Oxford.

Sacks, Harvey - Emanuel A. Schegloff 1979. Two preferences in the organization of reference to persons in conversation and their interaction. In: Psathas $(1979,15-$ 21).

Acta Linguistica Hungarica 52, 2005 
Schegloff, Emanuel A. 1979. Identification and recognition in telephone conversation openings. In: Psathas (1979, 23-78).

Schegloff, Emanuel A. - Gail Jefferson - Harvey Sacks 1977. The preference for selfcorrection in the organization of repair in conversation. In: Language $53: 361-82$.

Taylor, Talbot J.--Deborah Cameron 1987. Analysing conversation: Rules and units in the structure of talk. Pergamon Press, Oxford.

Toolan, Michael 1989. Ruling out rules in the analysis of conversation. In: Journal of Pragmatics $13: 251-74$.

Vuchinich, Samuel 1990. Sequencing of terminations in family disputes. In: Allen Grimshaw (ed.): Conflict talk: Sociolinguistic investigations of arguments in conversations, 118-38. Cambridge University Press, Cambridge.

Address of the author: Ágnes Lerch

Department of General Linguistics

University of Szeged

Egyetem utca 2.

H-6722 Szeged

Hungary

lerch@hung.u-szeged.hu 